\title{
The Differences in Maternal Compliance in Completing Basic Immunization between Two Groups
}

\author{
Ita Susanti, ${ }^{1}$ Dewi Marhaeni Diah Herawati, ${ }^{2}$ Eddy Fadlyana, ${ }^{3}$ Herry Herman, ${ }^{4}$ \\ Kusnandi Rusmil, ${ }^{3}$ Firman Fuad Wirakusumah ${ }^{5}$ \\ ${ }^{1}$ Midwifery Master Study Program, Faculty of Medicine, Universitas Padjadjaran, Bandung, Indonesia, \\ ${ }^{2}$ Department of Public Health, Faculty of Medicine, Universitas Padjadjaran, Bandung, Indonesia, ${ }^{3}$ Department \\ of Child Health, Faculty of Medicine, Universitas Padjadjaran/Dr. Hasan Sadikin General Hospital, Bandung, \\ Indonesia, ${ }^{4}$ Department of Orthopaedics and Traumatology, Faculty of Medicine, Universitas Padjadjaran/Dr. \\ Hasan Sadikin General Hospital, Bandung, Indonesia, ${ }^{5}$ Department of Obstetrics and Gynecology, Faculty of \\ Medicine, Universitas Padjadjaran/Dr. Hasan Sadikin General Hospital, Bandung, Indonesia
}

\begin{abstract}
Immunization programs are implemented in Indonesia since 1956. Although the government has established a complete basic immunization program for infants aged o-12 months, there are still more than 1.4 million child deaths in the world each year due to various infectious diseases. The diseases can be prevented by immunization. Low basic immunization coverage in infants is related to parental non-compliance in fulfilling primary immunization. The purpose of this study was to measure the differences in maternal compliance in completing basic immunization in two groups. Samples are a group of mothers provided with Maternal Child Health (MCH) book and special booklet, and another group provided with $\mathrm{MCH}$ book only. This study used a quasi-experiment design with quantitative methods with a sample of 76 respondents chosen by simple random sampling-this research conducted in AugustOctober 2017 in Pir Batee Puteh Health Center, West Woyla district. The results indicate that there were differences in maternal compliance in completing basic immunization in mothers with $\mathrm{MCH}$ book and special booklet to mothers with only $\mathrm{MCH}$ book. Immunization health education interventions based on the MCH book and special booklet can improve the mother's compliance in completing the baby's basic immunization.
\end{abstract}

Keywords: Booklet, compliance, $\mathrm{MCH}$ book

\section{Perbedaan Kepatuhan Ibu dalam Melengkapi Imunisasi Dasar antara Dua Kelompok}

\begin{abstract}
Abstrak
Program imunisasi mulai dilaksanakan di Indonesia sejak tahun 1956. Meskipun pemerintah telah menetapkan program imunisasi dasar lengkap pada bayi usia 0-12 bulan, masih terdapat lebih dari 1,4 juta kematian anak di dunia setiap tahun karena berbagai penyakit menular yang pada dasarnya dapat dicegah dengan imunisasi. Cakupan imunisasi dasar yang rendah pada bayi berkaitan dengan ketidakpatuhan orangtua dalam memenuhi kelengkapan imunisasi dasar. Tujuan penelitian ini adalah mengukur perbedaan kepatuhan ibu dalam memenuhi kelengkapan imunisasi dasar pada dua kelompok. Sampel adalah kelompok ibu yang diberikan buku Kesehatan Ibu dan Anak (KIA) dan booklet, serta kelompok ibu yang diberikan buku KIA saja. Penelitian ini menggunakan desain quasy-experiment dan metode kuantitatif dengan sampel 76 responden yang dipilih secara simple random sampling. Penelitian dilakukan pada Agustus-Oktober 2017 di wilayah kerja Puskesmas Pir Batee Puteh, Kecamatan Woyla Barat. Hasil penelitian menunjukkan bahwa terdapat perbedaan kepatuhan ibu dalam memenuhi kelengkapan imunisasi dasar pada ibu yang diberikan buku KIA dan booklet dengan ibu yang hanya diberikan buku KIA. Intervensi pendidikan kesehatan imunisasi berdasar atas buku KIA dan booklet dapat meningkatkan pengetahuan dan kesadaran ibu tentang pentingnya imunisasi pada bayi sehingga meningkatkan kepatuhan ibu dalam melengkapi imunisasi bayinya.
\end{abstract}

Kata kunci: Booklet, buku KIA, kepatuhan

Received: 14 December 2017; Revised: 2 April 2019; Accepted: 26 April 2019; Published: 31 December 2020

Correspondence: Ita Susanti. Master Study Program, Faculty of Medicine, Universitas Padjadjaran. Gedung Rumah Sakit Pendidikan Universitas Padjadjaran. Jln. Prof. Eyckman No. 38, Bandung 40161, West Java, Indonesia. E-mail: itasusanti1990@gmail.com 


\section{Introduction}

The vaccine is one of the achievements of public health programs that must be improved to realize the degree of public health. The National Association of School Nurses (NASN) in Northern Indiana supports routine vaccination as recommended by the Advisory Committee on Immunization programs and supports local regulations on vaccination of students in schools. ${ }^{1}$ In some states, including the United States, it is missing the goal of preventing disease with the use of vaccination. These barriers have been placed in three broad categories namely health care system barriers, healthcare provider barriers, and patient barriers. ${ }^{2}$ Immunization programs began in Indonesia in $1956 .{ }^{3}$ Although the government has established a complete basic immunization program for infants aged $0-12$ months, there are still more than 1.4 million child deaths in the world each year caused by various infectious diseases that can be prevented by immunization. ${ }^{4}$

Children born with the assistance of a traditional birth attendant were much lower in rural areas. This reflects the distribution of ruralurban health personnel in Indonesia and most developing countries. ${ }^{5}$ Although the first dose of the measles vaccine is not given to children aged 9 months, the availability of traditional birth attendants at birth appears to predict vaccination coverage. Thus, the availability of qualified health personnel is likely to continue immunization into early childhood. Besides, the availability of traditional birth attendants can also affect measles vaccination. For example, a study of inequality in maternal and child health in Asia-Pacific found that the overall geographic, and socio-economic context, contributed to $75 \%$ of the inequality of skilled midwives in Indonesia. ${ }^{6}$ In particular, wealth contributed $27 \%$ and maternal education $12 \%$ to inequality. This determinant reflects the main determinant of identified inequality in measles vaccination. Also, other research results indicate that several other factors affect the completeness of the communication, namely individual, socio-cultural, and political factors. ${ }^{7}$

Based on the results of the Basic Health Research (Riskesdas) survey in Indonesia in 2013, DPT-HB-3 immunization coverage increased to $75.6 \% .{ }^{8}$ Despite the increase; the coverage was not evenly distributed across all regions in Indonesia. The coverage is not good enough which can be seen by diptheria incidence. The incidence of diphtheria in Indonesia in 2012 reached a high of 1,192 cases, decreased to 767 cases in 2013 , then 394 cases in 2014, and increased by 502 cases in 2015. ${ }^{9}$ Nationally; pneumonia cases increased by $63.45 \%$ in $2015 .{ }^{4}$ While hepatitis B cases reached $21.8 \%$ in $2013 .{ }^{3}$ Based on the survey, cases of diphtheria found in $37 \%$ of patients who had not received triple DPT dose immunization. ${ }^{9}$

Although Indonesia has succeeded in achieving polio-free certification with other South-East Asia Region (SEARO) countries in 2014, efforts to eradicate polio still have to be continued. The effort is important since if the coverage of polio immunization is low, it will enable the reemergence of polio cases in infants. ${ }^{9}$

Pir Batee Puteh Health Center at West Woyla district is one of the health centers in West Aceh regency, which has a fairly low level of pentavalent and polio immunization coverage every year. The coverage of pentavalent and polio immunization coverage in 2016 were pentavalent-1, pentavalent-2 and pentavalent 3 were $30.6 \%, 33.1 \%$ and $28.8 \%$ respectively. The polio-1 immunization coverage, polio-2, polio-3 and polio- 4 , were $43.1 \%, 36.3 \%, 31.9 \%$ and $34.4 \%$ respectively.

This study aims to measure the differences in maternal compliance in completing basic immunization between two groups. The study will provide a group of mothers with Maternal Child Health (MCH) book and special booklet, and another group provided with an MCH book only.

\section{Methods}

This study used a quantitative quasi-experimental design with a sample of 76 mothers who had babies that not received pentavalent- 1 and polio-2 immunization. The respondents were divided into two groups. One group as the intervention group provided with an MCH book and a special booklet, while the other group as the control, was only provided with the MCH book.

The development of the booklet used to improve maternal compliance in completing basic immunization for infants is as follows. Researchers developed a booklet based on a community needs analysis that aims to supplement the MCH book as a medium for immunization health education. The developed booklet content was assessed by a team from the Department of Child Health, Faculty of Medicine, Universitas Padjadjaran, Bandung. While a team 
from Visual Communication Design, Institut Teknologi Bandung assessed the media design. The results of the content assessment were then analyzed using Rasch modeling to produce a booklet that was suitable for use. The data in this study using SPSS with chi-square statistical tests to measure differences in maternal compliance in completing infant immunization. This research was conducted in August-October 2017 in the working area of the Pir Batee Puteh Health Center, West Woyla district. This study used two groups (cases and controls). Prior to the study, the two groups were given treatment, namely, the case group was given health education about immunization based on information in the $\mathrm{MCH}$ and booklet, while the control group was given health education about immunization based on information in the $\mathrm{MCH}$ book.

This research ethics is from the Health Research Ethics Committee at the Faculty of Medicine, Padjadjaran University, with the ethical approval number: 108/UN6.C.10/PN/2017.

\section{Results}

Table 1 showed the characteristic of respondents. Based on Table 1 there were no significant differences in age, education, and work in both groups ( $p>0.05)$. Thus, it can be concluded that the two groups of respondents have homogeneous characteristics.

Table 2 showed a significant difference in the improvement of maternal compliance in completing basic immunization in infants between the two groups. Compliance in the intervention group was 27 of 38 respondents compared to 17 of 38 respondents.

\section{Discussion}

The development of the booklet in this study aims to supplement the MCH book as a medium for immunization health education in order to increase maternal compliance in fulfilling the basic immunization for infants. Booklet is developed based on an analysis of community needs that provide information about immunizations and their problems. The booklet aims to supplement the information that is not available in the $\mathrm{MCH}$ handbook.

The results of this study showed significant differences in improving maternal compliance with basic immunization in infants.

The provision of $\mathrm{MCH}$ books can help

Table 1 Characteristic of Respondents

\begin{tabular}{lccc}
\hline \multirow{2}{*}{ Characteristics } & \multicolumn{2}{c}{ Groups } & \multirow{2}{*}{ p Value } \\
\cline { 2 - 3 } & Intervention (n=38) & Control (n=38) & \\
\hline Age & & & $0.754^{*}$ \\
$\quad$ Median (min-max) & $24.50(17-36)$ & $23.50(16-38)$ & \\
$\quad$ Average (SD) & $25.32(5.58)$ & $24.89(6.09)$ & \multirow{2}{*}{$0.956^{* *}$} \\
Education & & & \\
$\quad$ Elementary/equivalent & 9 & 9 & \\
Junior high school/equivalent & 15 & 9 & \multirow{2}{*}{$0.574^{* *}$} \\
Senior high school/equivalent & 10 & 3 & \\
$\quad$ University/academy & 4 & 9 & \\
Occupation & 7 & 29 & \\
$\quad$ Work & 31 & & \\
Not work & & 9 & \\
\hline
\end{tabular}

Note: * unpaired t test, ${ }^{* *}$ chi-square test

Table 2 Differences in Maternal Compliance in Completing Infant Immunization

\begin{tabular}{|c|c|c|c|}
\hline \multirow{2}{*}{ Compliance } & \multicolumn{2}{|c|}{ Groups } & \multirow{2}{*}{ p Value ${ }^{*}$} \\
\hline & Intervention $(n=38)$ & Control $(n=38)$ & \\
\hline Compliance & 27 & 17 & 0.02 \\
\hline Non-compliance & 11 & 21 & \\
\hline
\end{tabular}

Note: "chi-square test 
mothers improve their knowledge about the benefits and schedule of immunization. A complete recording will help mothers find out the type of immunization their babies received..$^{10}$ The distribution of $\mathrm{MCH}$ books, functioning as reminders of childhood immunization schedules. The book also acts as a simple health education media that is expected to increase knowledge and behavior about health, especially immunization. ${ }^{11}$

The research conducted by Osaki et al. ${ }^{12}$ stated that the use of the $\mathrm{MCH}$ book increases the awareness of parents and families to complete their infant immunization. They are recorded according to a predetermined schedule so that it can significantly increase immunization coverage in infants. The use of the $\mathrm{MCH}$ book is beneficial in the delivery of preventive health services, such as complete immunization for children.

Other research results show that the utilization of the MCH books accompanied by health education is effective in increasing immunization compliance and reducing immunization drop out rates. The main reason for immunization dropouts is an understanding of the benefits and immunization schedules that are lacking. ${ }^{13,14}$

Some of the results of previous studies indicate that the use of booklets in health education provides a significant increase in changes in individual behavior. The results of Bastable's research in Moura et al. ${ }^{15}$ showed that learning through reading, the average information obtained only reaches $10 \%$, while seeing can reach $20 \%$, and by listening, it can increase by $30 \%$. However, through booklets which combined new writing and drawing, the information obtained will be able to be absorbed to an average of $70 \%$. A booklet provided easier for message recipients to understand the health education material. The booklet showed that it would influence changes in individual behavior.

The results of the same study conducted by Owais et al. ${ }^{16}$ in Pakistan showed that health education interventions using easy-to-understand picture cards and very simple language were able to convey messages that could change people's behavior. The health education intervention using visual media was successful in increasing DPT-3 immunization coverage by $39 \%$.

In addition, there are several interventions designed to enhance changes in people's behavior toward immunization compliance. Based on the results of research conducted by Nelson et al. ${ }^{17}$ Showed that the study group that was given intervention with home visits, home- based vaccine health education, immunization education using visual images, and redesigned immunization cards, the complete immunization coverage increased by $19-20 \%$.

The results of the study by Uddin et al., ${ }^{18}$ home-based health education interventions coupled with on-site vaccines, health promotion, and enhanced immunization programs by helping patients to understand and utilize health services succeeded in increasing complete immunization coverage by $56 \%$ during the intervention period.

The results of a study conducted by Yu et al. ${ }^{19}$ on heart failure patients showed a significant difference in treatment compliance between the two groups $(p<0.001)$. Treatment compliance in the intervention group was better than the control group. The implementation of health education using booklets compiled according to patient information needs and effectively followed up by telephone can improve patient health and help patients maintain their physical, psychological, and social welfare to survive with heart failure. The use of booklets in health education is proven to improve patient adherence to treatment statistically.

The use of booklets, in addition to their low cost, is also easy to use as an educational medium that can integrate the latest evidencebased information in presenting standardized information. Henrotin et al., ${ }^{20}$ in their study, stated that a booklet was significantly effective in increasing patients' knowledge both in the long term and in the short term to increase patient adherence to exercise in reducing low back pain.

Claus et al.' $\mathrm{s}^{21}$ research state that booklet increase patient confidence in avoiding fear in performing postoperative physical activity significantly. It stated that the highly effective booklet media is used as a tool to organize health promotions for professionals in providing health education to patients. The result is because the information presented in the booklet is very structured with a combination of exciting writing and drawing. The key message conveyed is very clear and objective, making it easier for the message recipients to understand the messages conveyed.

\section{Conclusion}

It can be concluded that there are differences in maternal compliance in completing basic immunization in infants in a group with the $\mathrm{MCH}$ book and booklet compare to a group with only 
the $\mathrm{MCH}$ book.

\section{Conflict of Interest}

All authors stated that there no conflict of interest in this study.

\section{Acknowledgments}

The authors would like to thank the Pir Batee Puteh Health Center, West Woyla district, and respondents who participated in this study.

\section{References}

1. National Association of School Nurses. NASN position statement: immunizations. NASN Sch Nurse. 2011;26(2):121-2.

2. Hendriksz T, Malouf PJ, Sarmiento S, Foy JE. Overcoming patientbarriers to immunization. AOA Health Watch. 2013;8(3):9-14.

3. Peraturan Menteri Kesehatan Republik Indonesia Nomor 12 Tahun 2017 tentang Penyelenggaraan Imunisasi.

4. Kementerian Kesehatan Republik Indonesia. Profil kesehatan Indonesia tahun 2015. Jakarta: Kementerian Kesehatan Republik Indonesia; 2016.

5. Rannan-Eliya R. Review of the situation of equity in access to maternal and child health care in the Asia-Pacific region [Internet]. New York: UNICEF; 2008 [cited 2017 May 15]. Available from: http://www.unicef.org/ eapro/Unicef_VN_MNCH_Review_O4-22. pdf.

6. Rokx C, Giles J, Satriawan E, Marzoeki P, Harimurti P, Yavuz E. New insights into the provision of health services in Indonesia: a health workforce study. Washington DC: The International Bank for Reconstruction and Development/The World Bank; 2010.

7. Larson HJ, Jarrett C, Eckersberger E, Smith DM, Paterson P. Understanding vaccine hesitancy around vaccines and vaccination from a global perspective: a systematic review of published literature, 2007-2012. Vaccine. 2014;32(19):2150-9.

8. Badan Penelitian dan Pengembangan Kesehatan, Kementerian Kesehatan Republik Indonesia. Riset kesehatan dasar (Riskesdas 2013) [Internet]. Jakarta: Badan Penelitian dan Pengembangan Kesehatan, Kementerian Kesehatan Republik Indonesia; 2013 [cited 2017 May 15]. Available from: https://pusdatin.kemkes.go.id/resources/ download/general/Hasil\%20Riskesdas\%20 2013.pdf.

9. Pusat Data dan Informasi, Kementerian Kesehatan Republik Indonesia. Situasi imunisasi di Indonesia [Internet]. Jakarta: Pusat Data dan Informasi, Kementerian Kesehatan Republik Indonesia; 2016 [cited 2017 May 15]. Available from: https://pusdatin.kemkes.go.id/resources/ download/pusdatin/infodatin/InfoDatinImunisasi-2016.pdf.

10. Bhuiyan SU, Nakamura Y. Continuity of maternal, neonatal and child health care through $\mathrm{MCH}$ handbook for ensuring the quality of life. In: Proceedings of the $6^{\text {th }}$ International Conference on Maternal and Child Health (MCH) Handbook; 2008 November 8-10; Tokyo, Japan. Osaka: Osaka University; 2009 January 1 [cited 2017 March 28]. p. 1-6. Available from: https:// www.childresearch.net/RESOURCE/ RESEARCH/2009/exfile/BHUIYAN NAKAMURA.pdf.

11. Osaki K, Hattori T, Kosen S, Singgih B. Investment in home-based maternal, newborn and child health records improves immunization coverage in Indonesia. Trans R Soc Trop Med Hyg. 2009;103(8):846-8.

12. Osaki K, Hattori T, Kosen S, Singgih B. Investment in home-based maternal, newborn and child health records improves immunization coverage in Indonesia. Royal Soci Trop Med Hygiene. 2009;103:846

13. Odusanya OO, Alufohai EF, Meurice FP, Ahonkhai VI. Determinants of vaccination coverage in rural Nigeria. BMC Public Health. 2008;8:381.

14. Usman HR, Akhtar S, Habib F, Jehan I. Redesigned immunization card and centerbased education to reduce childhood immunization dropouts in urban Pakistan: a randomized controlled trial. Vaccine. 2009;27(3):467-72.

15. Moura DJM, Moura NDS, Menezes LCG, Barros AA, Guedes MVC. Development of a booklet on insulin therapy for children with diabetes mellitus type 1. Rev Bras Enferm. 2017;70(1):7-14.

16. Owais A, Hanif B, Siddiqui AR, Agha A, Zaidi AK. Does improving maternal knowledge of vaccines impact infant immunization rates? A community-based randomized-controlled trial in Karachi, Pakistan. BMC Public Health. 
2011;11:239.

17. Nelson KN, Wallace AS, Sodha SV, Daniels D, Dietz V. Assessing strategies for increasing urban routine immunization coverage of childhood vaccines in low and middle-income countries: a systematic review of peer-reviewed literature. Vaccine. 2016;34(46):5495-503.

18. Uddin MJ, Larson CP, Oliveras E, Khan A, Quaiyum M, Saha NC. Child immunization coverage in urban slums of Bangladesh: impact of an intervention package. Health Policy Plan. 2010;25(1):50-60.

19. Yu M, Chair SY, Chan CWH, Choi KC. A health education booklet and telephone follow-ups can improve medication adherence, healthrelated quality of life, and psychological status of patients with heart failure. Heart Lung. 2015;44(5):400-7.

20. Henrotin YE, Cedraschi C, Duplan B, Bazin T, Duquesnoy B. Information and low back pain management: a systematic review. Spine. 2016;31(11): E326-34.

21. Claus D, Coudeyre E, Chazal J, Irthum B, Mulliez A, Givron P. An evidence-based information booklet helps reduce fearavoidance beliefs after first-time discectomy for disc prolapse. Ann Phys Rehabil Med. 2017;60(2):68-73. 